\title{
PENERAPAN TEORI SELF CARE OREM DALAM ASUHAN KEPERAWATAN PASIEN DIABETES MELITUS
}

\author{
Mario Esau Katuuk $^{1}$, Ratna Sitorus ${ }^{2}$, Lestari Sukmarini ${ }^{3}$ \\ 1. Program Studi Ilmu Keperawatan, Fakultas Kedokteran, Universitas Sam Ratulangi, Jln. Kampus Unsrat Kleak, \\ Manado, 95115, Indonesia \\ 2. Keilmuan Keperawatan Medikal Bedah, Fakultas Ilmu Keperawatan, Universitas Indonesia, Kampus FIK UI \\ Jln. Prof. Dr. Bahder Djohan, Depok, 16424, Indonesia \\ 3. Keilmuan Keperawatan Medikal Bedah, Fakultas Ilmu Keperawatan, Universitas Indonesia, Kampus FIK UI \\ Jln. Prof. Dr. Bahder Djohan, Depok, 16424, Indonesia
}

Email: rio.esau@gmail.com

\begin{abstract}
Abstrak
Diabetes melitus merupakan sekelompok gangguan metabolisme tubuh, ditandai dengan hiperglikemik kronis yang dapat mengakibatkan komplikasi akut dan kronis. Salah satu peran perawat sebagai pemberi asuhan adalah memberikan asuhan keperawatan yang berkualitas melalui pendekatan Teori Self Care Orem. Penggunaan pendekatan teori ini diharapkan dapat membantu perawat dalam menanggulangi keterbatasan yang dimiliki pasien dan melibatkan pasien secara aktif dalam proses perawatannya melalui peilaku perawatan mandiri. Tujuan penulisan karya ilmiah akhir ini adalah menganalisis hasil proses belajar praktik klinik keperawatan medikal bedah melalui penerapan asuhan keperawatan, penerapan evidence based nursing practice, dan inovasi keperawatan. Data yang diperoleh selama praktik klinik menunjukkan sebagian besar pasien diabetes melitus mengalami komplikasi ulkus kaki diabetik yang disebabkan oleh perilaku perawatan kaki mandiri belum optimal. Hasil penerapan evidence based nursing practice berupa kegiatan edukasi perawatan kaki mandiri dapat meningkatkan pengetahuan dan membentuk perilaku perawatan kaki sebagai tindakan pencegahan dini. Hasil kegiatan inovasi keperawatan melalui pengkajian kesehatan mandiri adalah pasien dapat melakukan pengkajian mandiri terhadap kebutuhan edukasi dan mendapatkan edukasi sesuai kebutuhan mereka. Kesimpulan dari karya ilmiah akhir ini adalah perlunya peningkatan kualitas asuhan keperawatan pada pasien diabetes melitus melalui pendekatan teori keperawatan untuk meningkatkan kemandirian pasien dalam pengelolaan penyakitnya.
\end{abstract}

Kata kunci: Diabetes Melitus, Teori Self Care Orem, Edukasi Perawatan Kaki Mandiri, Pengkajian Kesehatan Mandiri

\begin{abstract}
Diabetes mellitus is a metabolic disorder that characterized by chronic hyperglycemia which could lead to acute and chronic complications. One of nurse roles in managing diabetes mellitus is deliver nursing care using Orem's Theory of Self Care as guide of nursing practice. With this theoretical approach, nursing is expected to be able to overcome the limitations and inability of the patients and actively involve patients in the treatment process through self-care behaviors. The aims of this paper is to analyze the implementation of nursing care, application of evidence based nursing practice, and innovation program which integrated to clinical practice. Based on patient collective data, it was found that the majority of diabetes mellitus patients had been hospitalized with diabetic foot ulcers complications that caused by non-optimal foot self-care behavior. The results of evidence based nursing practice showed that the diabetic foot care education program can improve the knowledge and build the foot self-care behavior as early prevention action. The results of innovation program through self-health assessment program showed that patients could assess their needs and get health education according to the assessment results. In conclusion, it's needed to improve the quality in caring for diabetes mellitus patients through application of nursing theory to increase the self-care behaviors in management of disease.
\end{abstract}

Keywords: Diabetes Mellitus, Orem's Theory of Self Care, Diabetic Foot Care Education, Self-Health Assessment. 


\section{PENDAHULUAN}

Diabetes melitus (DM) merupakan salah satu penyakit tidak menular dengan peningkatan jumlah kasus yang signifikan dari tahun ke tahun. Pada tahun 2003, World Health Organization (WHO) memperkirakan 194 juta jiwa atau 5,1\% dari 3,8 miliar penduduk dunia yang berusia 20-79 tahun menderita DM dan data tahun 2011 menunjukkan bahwa penduduk dunia yang menderita DM mengalami peningkatan menjadi 346 juta jiwa. Data yang dikeluarkan oleh International Diabetes Federation (IDF) menyebutkan jumlah penderita diabetes melitus pada tahun 2013 mengalami peningkatan menjadi 382 juta orang. Menurut IDF angka ini akan terus meningkat dan diestimasikan jumlah penderita DM akan bertambah menjadi 592 juta orang pada tahun 2035 (IDF, 2013). Peningkatan prevalensi DM yang mencolok terjadi pada kasus DM tipe 2, dimana terjadi peningkatan jumlah kasus di berbagai negara. Salah satu negara dengan peningkatan insidensi diabetes melitus adalah Indonesia. Data dari IDF (2013) menunjukkan bahwa Indonesia berada pada peringkat ke tujuh dunia dalam sepuluh negara dengan kasus DM terbanyak yaitu 8,5 juta orang.

Diabetes melitus merupakan sekelompok gangguan metabolisme yang ditandai dengan hiperglikemia dan komplikasi yang khas termasuk penyakit aterosklerosis kardiovaskuler prematur dan penyakit pembuluh darah kecil yang dimanifestasikan sebagai retinopati dengan potensi kehilangan fungsi penglihatan; nefropati yang dapat menyebabkan gagal ginjal; dan neuropati perifer dengan resiko tinggi ulkus kaki diabetik dan amputasi (Leu \& Zonszein, 2010). Kondisi hiperglikemia yang tidak terkontrol dapat mengakibatkan berbagai komplikasi akut (ketoasidosis diabetikum, hiperglikemik hyperosmolar non ketotik, hipoglikemia) dan kronis (penyakit jantung koroner, retinopati, nefropati, neuropati) (Waspadji, 2013). Komplikasi yang muncul menjadi penyebab utama peningkatan angka morbiditas dan mortalitas pada kasus diabetes melitus.

Keperawatan sebagai suatu profesi memberikan pelayanan profesional kepada pasien dengan teliti, aman, dan kompeten. Perawat bertanggungjawab untuk memperoleh dan memelihara pengetahuan dan kemampuan yang spesifik sebagai bentuk tanggung jawab dan peran secara profesional. Beberapa peran perawat diantaranya pemberi asuhan, sebagai advokat, edukator, komunikator, manajer, dan inovator (Potter, Perry, Stockert, \& Hall, 2013). Dalam mengimplementasikan pelayanan keperawatan yang profesional, perawat harus melakukan interaksi dengan pasien dan keluarga sehingga terbentuk sebuah hubungan saling percaya antara perawatpasien.

Pengelolaan diabetes melitus yang komprehensif tidak lepas dari peran ilmu keperawatan dengan pelayanan keperawatan profesional. Dalam memberikan asuhan keperawatan profesional, beberapa hal yang dapat dilakukan adalah dengan penerapaan teori keperawatan sebagai petunjuk asuhan keperawatan, memberikan intervensi keperawatan berdasarkan evidence based, dan membuat terobosan melalui inovasi keperawatan.

Pelayanan asuhan keperawatan dilaksanakan berdasarkan kiat dan ilmu keperawatan yang diintegrasikan dalam pelayanan melalui penerapan teori keperawatan dalam hal ini Teori Self Care Orem. Teori ini dipandang sesuai dengan kasus diabetes melitus sebagai suatu kondisi kronis yang manajemen penatalaksanaannya bergantung pada self care pasien (Gabbay \& Adelman, 2010). Dalam proses pemberian asuhan keperawatan dengan menggunakan pendekatakan Teori Self Care Orem, perawat membantu pasien memenuhi kebutuhan sesuai kebutuhan self care pasien yaitu whole compensatory, partly compensatory dan supportive educative. 
Dalam proses pendidikan ners spesialis ini, selain menjalankan peran dan fungsi sebagai pemberi asuhan keperawatan, penulis menjalankan fungsi sebagai perawat peneliti. Perawat peneliti mengidentifikasi masalah dalam pelayanan keperawatan dan meningkatkan pelayanan asuhan keperawatan. Fungsi ini berjalan dalam proses pemberian asuhan keperawatan berbasis bukti (evidence based practice). Penulis melihat sebuah fenomena yaitu tingginya angka komplikasi penyakit kaki diabetik pada pasien diabetes melitus. Tindakan pencegahan yang dapat dilakukan yaitu dengan melakukan perawatan kaki mandiri. Oleh karena itu, topik evidence based practice yang diangkat adalah edukasi perawatan kaki mandiri.

Peran Inovator diimplementasikan dalam bentuk kegiatan inovasi keperawatan. Peran sebagai inovator dilaksanakan bersama penulis kelompok endokrin dengan topik peningkatan promosi kesehatan melalui pemeriksaan dan pemantauan kesehatan mandiri pada pasien diabetes melitus. Program ini dilaksanakan dengan cara menyediakan fasilitas self-health assessment dan memberikan booklet yang berisi informasi dan catatan pemantauan untuk kendali diabetes.

Berdasarkan uraian tersebut, maka penulis menyusun karya ilmiah akhir tentang penerapan Teori Self Care Orem dalam asuhan keperawatan pasien diabetes melitus, yang berisi penjelasan dan pemaparan mengenai analisis kegiatan praktik klinik dalam pengelolaan pasien dengan masalah endokrin yaitu diabetes melitus.

\section{METODE}

\section{Laporan dan Analisa Kasus}

Penerapan teori Self Care Orem dalam asuhan keperawatan dilakukan dari proses pengkajian sampai evaluasi keperawatan. Pengkajian dilakukan menggunakan format dengan pendekatan teori Self Care Orem terhadap beberapa aspek yaitu Universal Self Care Requisites, Developmental Self Care Requisites, Health Deviation Self Care Requisites. Kebutuhan self care masingmasing individu disesuaikan dengan basic conditioning factors. Hasil pengkajian dianalisa untuk menentukan kebutuhan self care pasien, selanjutnya ditegakkan diagnosa keperawatan. Intervensi keperawatan diberikan menyesuaikan dengan kategori bantuan dalam Nursing System (wholly compensatory, partly compensatory, supportive-educative) dengan menggunakan pendekatan 5 metode bantuan yaitu doing for, guiding, supporting, providing environment for development of self care, teaching. Selanjutnya evaluasi dilakukan terhadap respon pasien dengan tujuan untuk pengkajian kembali therapeutic self care demamnd, dan kebutuhan self care disesuaikan kembali dengan nursing system.

\section{Penerapan Evidence Based Nursing Practice}

Penerapan praktek evidence based nursing practice (EBNP) ini dimulai dengan tahap persiapan yaitu penulis mencari fenomena di lapangan yang menimbulkan masalah dan membutuhkan intervensi untuk memperbaiki masalah tersebut, selanjutnya melakukan penelusuran literatur dan menyusun proposal. Berdasarkan hasil observasi, penulis menemukan proses edukasi perawatan kaki mandiri terhadap pasien diabetes melitus dilakukan di klinik kaki diabetes dengan cara memberikan edukasi sementara perawat melakukan perawatan kaki pasien (edukasi opportunistik). Hal ini mengakibatkan topik yang dibicarakan tidak terstruktur dan tidak mencakup keseluruhan materi yang seharusnya diberikan. Oleh karena itu, dibutuhkan metode edukasi yang dapat diterapkan pada kondisi seperti ini. Setelah ditemukan fenomena di lapangan, penulis melanjutkan dengan melakukan penelusuran literatur untuk penyusunan proposal dan melakukan konsultasi dengan supervisor. 
Proses implementasi EBNP ini diawali dengan melakukan identifikasi pasien dengan menyebarkan flyer tentang pengkajian singkat masalah kaki diabetik dan pengetahuan tentang perawatan kaki dalam bentuk checklist. Selain itu penulis juga mengidentifikasi kondisi pasien sesuai kriteria inklusi yaitu mampu berkomunikasi dengan baik, mampu membaca dan menulis, tidak mengalami ulkus kaki diabetik, memiliki kemampuan penglihatan yang baik, dan bersedia mendapatkan edukasi perawatan kaki diabetik. Pasien yang masuk kriteria inklusi diberikan penjelasan mengenai tujuan, manfaat, proses pelaksanaan EBNP dan evaluasi. Pasien yang bersedia ikut serta dalam kegiatan ini diminta kesediaannya untuk menandatangi lembar informed consent sebagai bukti bersedia menjadi responden. Langkah selanjutnya adalah pasien mengisi kuesioner tentang pengetahuan perawatan kaki dan perilaku perawatan kaki. Setelah itu, penulis melakukan pemeriksaan kaki terhadap pasien menggunakan format yang telah disediakan. Selanjutnya pasien diberikan edukasi mengenai perawatan kaki diabetik, Materi edukasi yang diberikan tentang faktor resiko, masalah kaki diabetik, pemeriksaan dan perawatan kaki dengan media booklet dan perlengkapan perawatan kaki (cermin, kikir kuku, handuk, body lotion, dan sabun lembut). Setelah proses edukasi dan demontrasi, pasien mendemonstrasikan cara perawatan kaki yang sudah diajarkan sebelumnya.

\section{Inovasi Keperawatan}

Pelaksanaan program Inovasi Keperawatan dilakukan bersama kelompok mahasiswa Ners Spesialis Keperawatan Medikal Bedah peminatan Endokrin. Program ini diawali dengan studi pendahuluan dan identifikasi fenomena di poliklinik endokrin metabolik. Studi pendahuluan yang dilakukan yaitu identifikasi jumlah kunjungan pasien DM di poliklinik metabolik endokrin dalam 3 bulan terakhir. Selajutnya, proses identifikasi fenomena dilakukan dan hasilnya adalah waktu tunggu pasien di poliklinik endokrin metabolik yang cukup lama sehingga dapat digunakan untuk kegiatan promosi kesehatan dengan pemeriksaan dan pemantauan kesehatan mandiri melalui self health assessment. Dalam proses ini juga dilakukan konsultasi dengan supervisor. Selanjutnya dilakukan adalah membuat rancangan model promosi kesehatan. Model promosi kesehatan yang dirancang adalah dengan self health assessment dan edukasi. Proses self health assessment dilakukan dengan menyediakan flyer berisi quick quiz yang diisi oleh pasien. Topik yang dikaji melalui self health assessment adalah pengetahuan tentang DM, perilaku perawatan diri, pengetahuan tentang resiko hipoglikemi, dan resiko komplikasi kaki diabetik. Selain flyer, disediakan juga banner yang berisi pertanyaan quick quiz yang dirancang agar terlihat menarik, informatif, dan mudah dibaca. Sebagai bentuk tindak lanjut dari self health assessment, proses selanjutnya adalah edukasi manajemen pengelolaan diabetes melitus. Pembuatan booklet edukasi "Sahabat Diabetes" dibuat sebagai media edukasi, pemantauan, dan komunikasi pasien.

Pelaksanaan proyek inovasi telah dilaksanakan pada awal bulan Mei 2015 selama 5 hari. Proses awal yang dilakukan adalah dengan melakukan sosialisas kegiatan kepada pasien yang ada di ruang tunggu poliklinik. Program ini dilaksanakan dengan memanfaatkan waktu tunggu pasien DM sebelum di panggil ke ruangan dokter. Setelah dilakukan sosialisasi, penulis membagikan flyer quick quiz kepada pasien DM. Pasien DM diminta untuk mengisi quick quiz yang didampingi oleh penulis. Setelah proses pengisian selesai, hasil quick quiz akan dikategorikan berdasarkan masingmasing topik. Self Health Assessment terdiri dari 4 topik, yaitu perilaku perawatan diri, pengetahuan tentang resiko hipoglikemi, dan resiko komplikasi kaki diabetik , dan setiap topik memiliki kategori yang menjadi acuan untuk kebutuhan belajar pasien. Total flyer yang disebarkan yaitu 40, masing-masing 10 
tiap topik. Pasien yang terjaring dan memiliki kebutuhan belajar mendapatkan edukasi manajemen diabetes melitus oleh penulis.

\section{HASIL}

\section{Asuhan Keperawatan 30 Kasus Kelolaan}

Berdasarkan analisa terhadap 30 kasus kelolaan penulis, ditemukan bahwa terdapat beberapa komplikasi baik akut maupun kronis yang menjadi penyebab perawatan pasien diabetes melitus di rumah sakit. Data dari 30 pasien yang dikelola oleh penulis, komplikasi kronis yang paling banyak adalah ulkus kaki diabetik, yang pada beberapa pasien disertai dengan komplikasi akut seperti KAD, dan komplikasi kronis seperti neuropati, CHF, dan CKD. Ulkus kaki diabetik sering disertai dengan KAD akibat hiperglikemia yang distimulasi oleh infeksi kaki diabetik. Sedangkan sebagian besar pasien yang berkunjung ke poliklinik endokrin memiliki masalah komplikasi kaki diabetik seperti ulkus kaki diabetik dan neuropati. Komplikasi kronis pada pasien diabetes melitus sering terjadi bersamaan yang meningkatkan tingkat kompleksitas penyakit.

\section{Kasus Kelolaan Utama}

Asuhan keperawatan kelolaan utama dilakukan pada kasus Tn. R dengan Diabetes Melitus tipe $2+$ Congestive Heart Failure (CHF) Grade II + Community Acquired Pneumonia (CAP) + Efusi Pleura Bilateral + Ulkus diabetik pedis sinistra post debridement. Masalah keperawatan yang muncul adalah gangguan pertukaran gas, resiko ketidakstabilan kadar glukosa darah, kelebihan volume cairan, kerusakan integritas jaringan, dan resiko ketidakseimbangan elektrolit.

\section{Penerapan Evidence Based Nursing Practice}

Diagram 1. Skor Perilaku Perawatan Kaki

Diabetik Sebelum dan Sesudah Intervensi $(\mathrm{N}=7)$

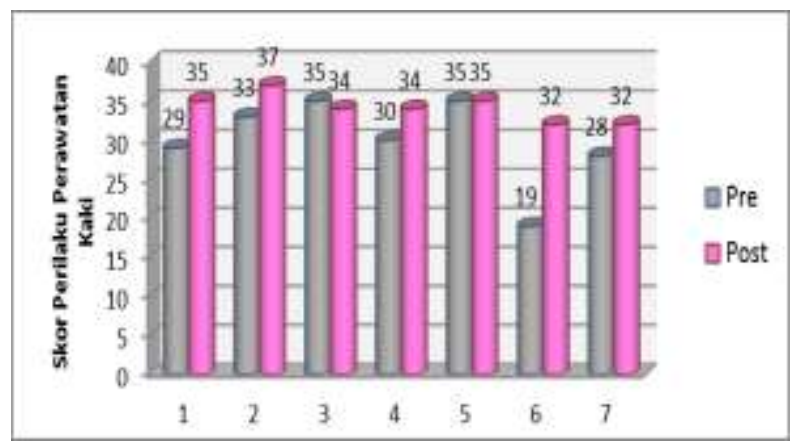

Diagram 2. Skor Pengetahuan Perawatan Kaki Diabetik Sebelum dan Sesudah Intervensi $(\mathrm{N}=7)$

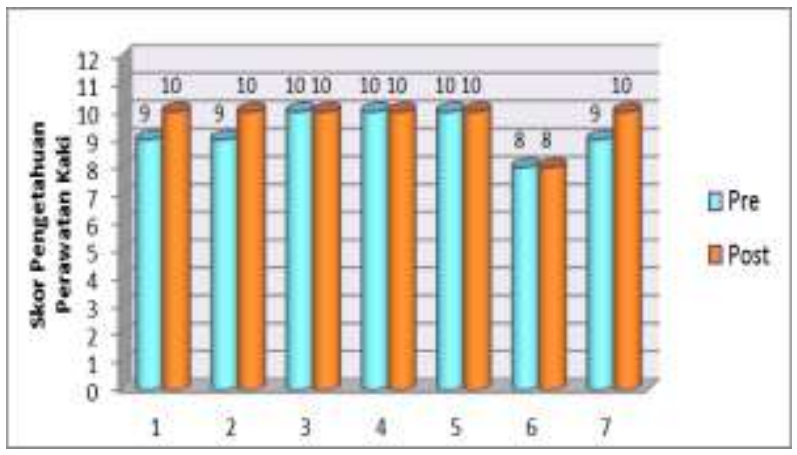

Diagram 3. Perbandingan Rerata Skor Perilaku Perawatan Kaki Sebelum dan Sesudah Intervensi

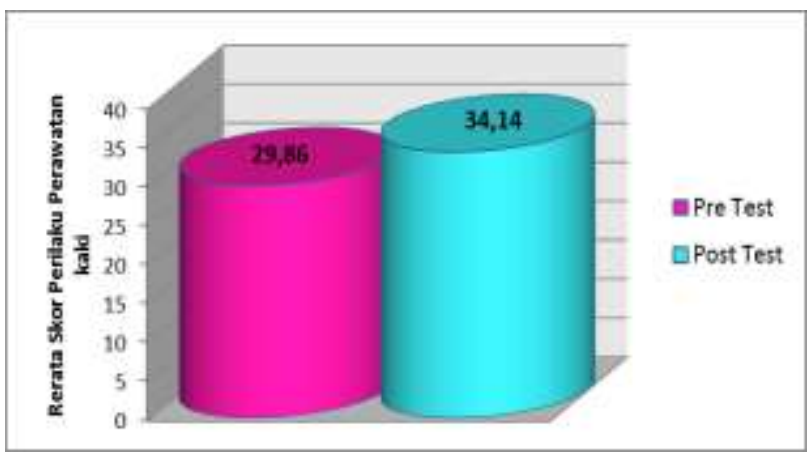


Diagram 4. Perbandingan Rerata Skor Pengetahuan Perawatan Kaki Sebelum dan Sesudah Intervensi

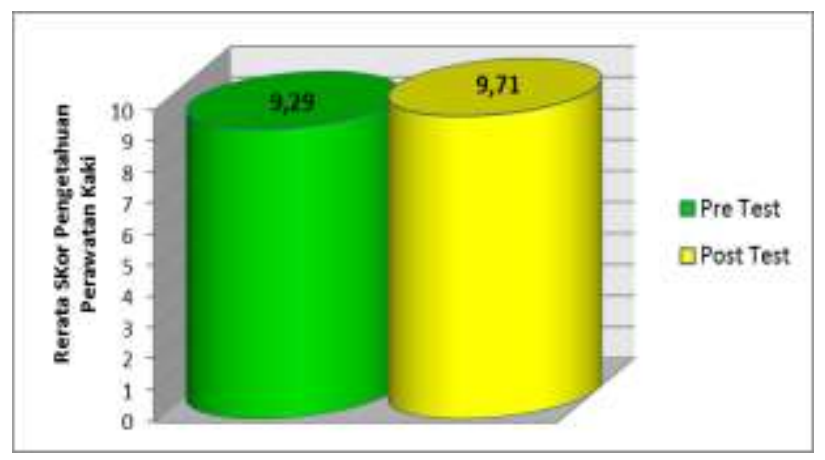

Tabel 1. Gambaran Persepsi Pasien Terhadap Booklet Edukasi Perawatan Kaki Mandiri

\begin{tabular}{lcccc}
\hline \multicolumn{1}{c}{ Penilaian } & $\begin{array}{c}\text { Sangat } \\
\text { Baik }\end{array}$ & Baik & $\begin{array}{c}\text { Cukup } \\
\text { Baik }\end{array}$ & $\begin{array}{c}\text { Tidak } \\
\text { Baik }\end{array}$ \\
\hline $\begin{array}{l}\text { Informasi jelas } \\
\text { dan dimengerti }\end{array}$ & 6 & 1 & 0 & 0 \\
\hline Tulisan jelas & 6 & 1 & 0 & 0 \\
\hline $\begin{array}{l}\text { Tampilan dan } \\
\text { warna gambar } \\
\text { jelas }\end{array}$ & 6 & 1 & 0 & 0 \\
\hline $\begin{array}{l}\text { Bahasa mudah } \\
\text { dimengerti }\end{array}$ & 6 & 1 & 0 & 0 \\
\hline $\begin{array}{l}\text { Metode } \\
\text { penyuluhan }\end{array}$ & 5 & 2 & 0 & 0 \\
\hline Manfaat booklet & 6 & 1 & 0 & 0 \\
\hline
\end{tabular}

\section{Inovasi Keperawatan}

Tabel 2. Hasil analisis gambaran umur dan lama DM responden Inovasi Keperawatan di Poliklinik Endokrin $(\mathrm{N}=16)$

\begin{tabular}{ccc}
\hline Variabel & Mean \pm SD & 95 \% CI \\
\hline Umur & $54,31 \pm 7,507$ & $50,31-58,31$ \\
Lama DM & $8,88 \pm 6,81$ & $5,25-12,5$ \\
\hline
\end{tabular}

Tabel 3. Distribusi frekuensi berdasarkan jenis kelamin dan tingkat pendidikan responden Inovasi Keperawatan di Poliklinik Endokrin $(\mathrm{N}=16)$

\begin{tabular}{lcc}
\hline \multicolumn{1}{c}{ Data } & Jumlah & $\begin{array}{c}\text { Persentase } \\
(\boldsymbol{\%})\end{array}$ \\
\hline Jenis Kelamin & & \\
Laki- laki & 8 & 50 \\
Perempuan & 8 & 50 \\
\hline Tingkat Pendidikan & & \\
Rendah (SD, SMP) & 2 & 12,4 \\
Menengah & 8 & 50 \\
(SMA/SMK) & & \\
Tinggi (Akademi, PT) & 6 & 37,4 \\
\hline
\end{tabular}

Diagram 3.5. Gambaran tingkat kepuasan responden terhadap program Inovasi Keperawatan

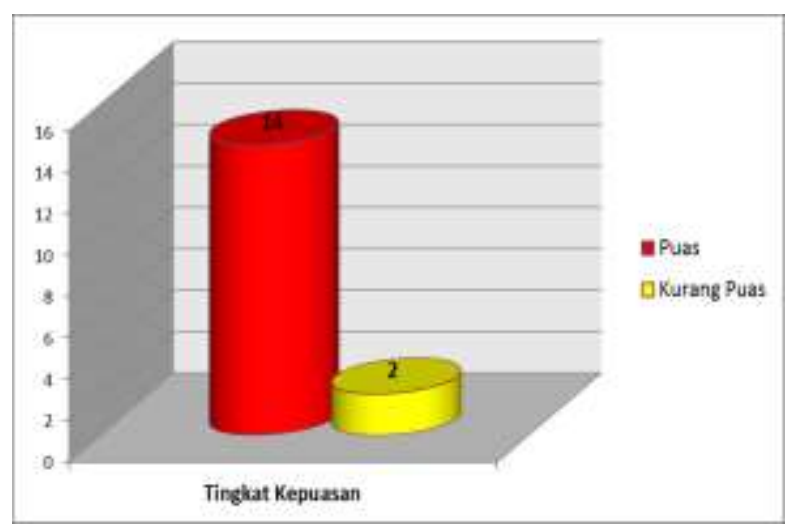

\section{PEMBAHASAN}

\section{Asuhan Keperawatan 30 Kasus Kelolaan}

Data dari 30 pasien yang dikelola oleh penulis, komplikasi kronis yang paling banyak adalah ulkus kaki diabetik, yang pada beberapa pasien disertai dengan komplikasi akut seperti KAD, dan komplikasi kronis seperti CHF, dan CKD. Ulkus kaki diabetik sering disertai dengan KAD akibat hiperglikemia yang distimulasi oleh infeksi kaki diabetik. Fakta bahwa ulkus 
kaki diabetik menjadi penyebab pasien diabetes melitus menjalani hospitalisasi ini senada dengan hasil penelitian yang dilakukan oleh Lavery, Armstrong, Wunderlich, Mohler, Wendel, \& Lipsky (2006) yang menyebutkan bahwa pasien diabetes melitus yang mengalami infeksi ulkus kaki beresiko 55,7 kali lebih besar mengalami hospitalisasi dibandingkan dengan yang tidak mengalami komplikasi ini.

Peningkatan angka kesakitan pasien diabetes melitus akibat komplikasi yang muncul akan mempengaruhi kualitas hidup pasien. Beberapa faktor yang mempengaruhi perkembangan komplikasi diabetes melitus diantaranya lama mengalami diabetes melitus, kontrol glikemik, hipertensi, riwayat merokok, profil lipid. Pencegahan terhadap perkembangan komplikasi diabetes melitus sangat penting dilakukan. peran perawat sebagai edukator adalah dengan memberikan edukasi kepada pasien diabetes melitus tentang perjalanan komplikasi penyakit diabetes melitus dan pencegahannya, pengelolaan diabetes melitus, dan perubahan perilaku gaya hidup. Hal ini harus terintegrasi dengan pengelolaan diabetes melitus untuk mencapai kontrol glikemik dan kendali diabetes yang optimal. Selain itu, perawat spesialis harus memiliki kemampuan untuk melakukan deteksi dini terhadap tanda dan gejala komplikasi diabetes melitus baik akut maupun kronis (mikrovaskular dan makrovaskular). Deteksi dini terhadap komplikasi melalui skrining secara berkala akan memberikan peluang penatalaksanaan lebih awal sehingga dapat mencegah atau menunda perkembangan komplikasi (Loveman, Royle, \& Waugh, 2009; Marshall \& Flyvbjerg, 2006).

Penerapan asuhan keperawatan dengan menggunakan pendekatan Teori Self Care Orem melewati beberapa tahap proses keperawatan. Pada tahap awal atau diagnostic operation, merupakan tahap dimana perawat membina hubungan antara pasien dan perawat/keluarga. Tujuan proses ini adalah untuk menciptakan hubungan saling percaya antara perawat dan pasien, karena kepercayaan merupakan elemen yang sangat penting dalam hubungan perawat pasien (Trojan \& Yonge, 1993).

Proses pengkajian terhadap kebutuhan therapeutic self care demand dilakukan pada tahap awal. Pengkajian faktor kondisi dasar dilakukan bersamaan dengan pengkajian kebutuhan perawatan diri universal, kebutuhan perawatan diri untuk mendukung perkembangan, dan kebutuhan perawatan diri akibat deviasi kesehatan. Analisa dilakukan untuk mengidentifikasi adanya keterbatasan atau ketidakmampuan dalam melakukan aktivitas perawatan mandiri. Kemudian ditegakkan diagnose keperawatan. Diagnosa keperawatan yang mayoritas ditegakkan pada 30 pasien yang penulis kelola adalah resiko ketidakstabilan glukosa darah. Masalah ini merupakan suatu kondisi dimana pasien beresiko terhadap variasi kadar glukosa darah dari rentang normal. Infeksi yang terjadi pada pasien diabetes melitus dan respon hospitalisasi merupakan stressor yang dapat meningkatkan proses metabolisme dan merangsang respon kontra regulasi sehingga terjadi proses pelepasan dan pembentukan glukosa melalui proses glikogenolisis dan gluconeogenesis di hepar. Hal ini mengakibatkan terjadinya peningkatan kadar glukosa darah. Sementara itu, asupan nutrisi yang tidak adekuat di tambah dengan pemberian insulin yang kurang tepat meningkatkan resiko terjadinya hipoglikemia.

Masalah keperawatan kedua yang banyak ditemukan adalah ketidakefektifan perawatan kesehatan. Hal ini berhubungan dengan angka kejadian ulkus kaki diabetik sebagai penyebab mayoritas hospitalisasi pada 30 pasien kelolaan. Selain karena efek komplikasi kronis yang mengakibatkan penyakit kaki diabetik, perawatan kaki yang tidak optimal merupakan salah satu prediktor terjadinya ulkus kaki diabetik. Ketidakpatuhan dalam pengelolaan diabetes melitus seperti perencanaan makan, 
latihan jasmani, dan pengobatan dapat dijelaskan berdasarkan hasil kontrol glikemik pasien yang buruk. Pada pasien yang memiliki data pemeriksaan $\mathrm{HbA1c}$, sebagian besar memiliki kadar $\mathrm{HbA} 1 \mathrm{c}>7 \%$. Hal ini menunjukkan kontrol glikemik pasien selama kurang lebih 3 bulan terakhir belum optimal. Kontrol glikemik yang buruk akan meningkatkan resiko berkembangnya komplikasi menjadi lebih buruk.

Masalah keperawatan selanjutnya yang banyak ditemukan adalah kerusakan integritas jaringan. Hal ini sejalan dengan angka kejadian ulkus kaki diabetik pada 30 pasien kelolaan. Pasien diabetes melitus beresiko mengalami komplikasi kaki diabetik yaitu neuropati (otonom, motoric, sensorik), penyakit arteri perifer, deformitas tulang, dan penurunan sistem imunitas. Kondisi tersebut dapat meningkatkan resiko terjadinya ulkus kaki diabetik yang terinfeksi. Jika terdapat faktor pencetus seperti trauma fisik, dapat terbentuk luka dan bisa berkembang menjadi buruk akibat proses infeksi. Pada penyakit arteri perifer, dimana terjadi gangguan sirkulasi perifer, dapat menyebabkan terjadinya critical limb ischaemic akibat ketidakadekuatan suplay darah. Jika disertai dengan perilaku perawatan kaki yang kurang optimal, maka resiko terjadi ulkus kaki diabetik akan semakin bertambah.

Masalah keperawatan yang lainnya muncul akibat respon terhadap kondisi patologis maupun prosedur tindakan diagnostic diantaranya pada pasien dengan komplikasi CHF dan CKD overload, ditemukan masalah kelebihan volume cairan, dan ketidakefektifan pola nafas akibat penumpukan cairan. Diagnosa ketidakseimbangan nutrisi ditegakkan berhubungan dengan intake nutrisi yang tidak adekuat akibat adanya gejala mual dan muntah. Masalah nyeri muncul pada pasien dengan ulkus kaki diabetik post tindakan pembedahan (debridement, amputasi, STSG), dan pada pasien dengan batu empedu dan post tindakan ERCP. Pada pasien diabetes melitus, efek dari kondisi hiperglikemik kronis akan mengganggu respon sistem imun sehingga terjadi penurunan sistem kekebalan tubuh yang menyebabkan pasien diabetes melitus rentan terserang infeksi dan perluasan infeksi.

Tahap selanjutnya yaitu prescriptive operations, tahap dimana perawat menentukan metode bantuan yang mungkin dapat diterapkan. Metode bantuan tersebut diantarya doing for, guiding and directing, teaching, dan providing. Tindakan yang dilakukan selalu berupaya untuk memenuhi kebutuhan perawatan diri untuk mencapai proses pemulihan pasien. Prioritas tindakan ditujukan kepada kebutuhan perawatan mandiri yang paling esensial yang dibutuhkan dalam proses fisiologis tubuh seperti oksigenasi. Pada tahap ini penulis membuat prioritas masalah berdasarkan tingkat kebutuhan esensial fisiologis, selanjutnya menentukan metode bantuan yang bisa dilakukan.

Tahap selanjutnya yaitu implementasi hasil tahap sebelumnya dalam regulatory operations untuk merancang, merencanakan dan menghasilkan suatu nursing system dengan mempertimbangkan hasil pengkajian pada tahap-tahap sebelumnya. Rencana intervensi dibuat dengan mempertimbangkan tingkat kebutuhan self-care pasien yang dibagi dalam wholly compensatory, partly compensatory dan supportive-educative. Pada 30 pasien kelolaan, sebagian besar tingkat kebutuhan pemenuhan self-care adalah partly compensatory dan supportive-educative. Hal ini terjadi akibat efek dari kondisi patologis penyakit yang mengakibatkan terjadi keterbatasan gerak bebas, termasuk dalam melakukan aktivitas perawatan mandiri, tetapi pasien masih mampu melakukan sebagian dari proses perawatan diri dan sebagian dibantu dan dilakukan oleh perawat. 


\section{Kasus Kelolaan Utama}

Pembahasan asuhan keperawatan kelolaan utama dilakukan pada kasus $\mathrm{Tn}$. $\mathrm{R}$ dengan Diabetes Melitus tipe $2+$ Congestive Heart Failure (CHF) Grade II + Community Acquired Pneumonia (CAP) + Efusi Pleura Bilateral + Ulkus diabetik pedis sinistra post debridement. Pada pengelolaan kasus ini ditemukan 6 diagnosa utama yaitu gangguan pertukaran gas, resiko ketidakstabilan kadar glukosa darah, kelebihan volume cairan, kerusakan integritas jaringan, dan resiko ketidakseimbangan elektrolit.

Gangguan pertukaran gas merupakan suatu kondisi kelebihan atau berkurangnya oksigenasi dan atau eliminasi karbondioksida pada membran alveolar-kapiler yang berhubungan dengan faktor yaitu perubahan pada membrane alveolar-kapiler darah, dan perubahan pada ventilasi dan perfusi (NANDA, 2011). Masalah gangguan pertukaran gas pada pasien $\mathrm{Tn}$. $\mathrm{R}$ ditandai dengan respon terhadap masalah pernapasan yang ditemukan yaitu sesak nafas, batuk berdahak, terdengar ronchi pada basal paru, hasil rontgen thoraks menunjukkan adanya efusi pleura dan edema paru, hasil pemeriksaan AGD dengan kesan alkalosis metabolik.

Gangguan pertukaran gas dapat dihubungkan dengan beberapa kondisi klinis suatu penyakit seperti pneumonia, penyakit paru kronis, atelectasis, sindrom distress pernapasan, massa paru, hernia diafragma. Selain itu, gangguan pertukaran gas juga dapat dipengaruhi oleh penurunan suplai darah pulmomal akibat hipertensi pulmonal, emboli paru, gagal jantung kongestif, dan anemia (Wilkinson, 2006). Pada pasien Tn. R, terdapat beberapa kondisi yang berhubungan dengan gangguan pertukaran gas yaitu adanya pneumonia (CAP) dan gagal jantung kongestif (CHF).

Intervensi keperawatan yang diberikan dalam kasus ini adalah pemantauan status pernafasan.
Monitor status pernafasan seperti frekuensi, kedalaman, dan suara nafas dilakukan untuk pemantauan perkembangan kondisi pasien. Pemantauan hasil pemeriksaan AGD serial dan elektrolit serta pemantauan tanda-tanda vital dilakukan setiap hari. Pengaturan posisi pasien dengan semi-fowler dilakukan untuk meningkatkan ventilasi dan oksigenasi (Ackley \& Ladwig, 2011). Pemberian terapi oksigen dilakukan dengan konsentrasi rendah (24-32\%) dengan aliran oksigen 3-4 L/menit menggunakan nasal kanul. Pemberian terapi oksigen pada pasien dengan hipoksemia ringan $\left(\mathrm{PO}_{2}\right)$ tidak anjurkan dengan konsetrasi tinggi karena tidak berdampak signifikan pada peningkatan ikatan $\mathrm{HbO}_{2}, \quad$ sebaliknya pemberian oksigen dengan konsentrasi tinggi dapat meracuni paru-paru dan menimbulkan efek merugikan (Price \& Wilson, 2005). Terapi farmakologis diberikan yaitu terapi inhalasi dan antibiotik.

Masalah keperawatan selanjutnya adalah resiko ketidakstabilan kadar glukosa darah. Resiko ketidakstabilan kadar glukosa darah merupakan suatu kondisi dimana pasien beresiko terhadap variasi kadar glukosa darah dari rentang normal. Beberapa faktor resiko kondisi ini seperti asupan diet, kurang kepatuhan pada manajemen diabetes, manajemen medikasi, status kesehatan fisik, stress dan infeksi (NANDA, 2010). Tujuan yang hendak dicapai dalam intervensi keperawatan untuk masalah tersebut adalah mempertahankan kadar glukosa darah dalam batas target pengobatan, mengidentifikasi faktor yang mengarah kepada ketidakstabilan glukosa darah. Merujuk kepada Teori Self Care Orem nursing system, pada awal pengkajian pasien $\mathrm{Tn}$. R berada pada partly compensatory system, dimana sebagian kebutuhan self care dibantu oleh perawat dan keluarga.

Gangguan metabolisme glukosa darah pada pasien diabetes melitus disebabkan oleh gangguan produksi dan kerja insulin. Selain itu hiperglikemia juga disebabkan oleh rendahnya 
respon jaringan tubuh terhadap insulin (resistensi insulin) yang terjadi secara bersamaan. Pada dasarnya diawali dengan gangguan penggunaan glukosa yang kemudian diikuti dengan peningkatan kadar glukosa darah (hiperglikemia) (Manaf, 2014; Alsahli \& Gerich, 2010).

Berdasarkan hasil pemeriksaan KGDH selama dirawat pasien Tn. $\mathrm{R}$ menunjukkan kadar glukosa darah yang fluktuatif dan cenderung mengalami hiperglikemia. Salah satu faktor yang berhubungan dengan hiperglikemia pada pasien yang dirawat adalah stress akibat kondisi penyakit dan infeksi. Pasien Tn. R didiagnosa mengalami CAP dan sepsis pada ulkus kaki diabetik terinfeksi. Infeksi yang terjadi pada pasien diabetes melitus terjadi akibat invasi kuman patogen dan akibat penurunan kemampuan sistem imunitas tubuh. Penurunan imunitas pada pasien diabetes melitus berhubungan dengan penurunan respon sel $\mathrm{T}$, fungsi neutrofil, dan gangguan imunitas humoral. Hal ini mengakibatkan pasien diabetes melitus rentan mengalami infeksi yang berkembang dan meluas sehingga sulit diatas (Casqueiro, Casqueiro, \& Alves, 2012). Hiperglikemi akibat stress metabolik disebabkan oleh kombinasi efek kerja beberapa hormon endogen, sitokin dan sistem signal sistem saraf kontra regulasi pada jalur metabolisme glukosa. Response inflamasi dan kontra regulasi terhadap kondisi penyakit atau infeksi akan mengganggu efek insulin dalam produksi glukosa hepar dan otot skelet. Stress akan menyebabkan peningkatan sekresi hormone kontra regulasi yaitu glukagon, epinefrin, norepinefrin, kortisol, dan hormon pertumbuhan yang akan menstimulasi glikogenolisis dan glukoneogenesis di hepar (Hammersley \& James, 2010).

Intervensi keperawatan yang diberikan berupa manajemen hiperglikemi. Dalam manajemen hiperglikemi, salah satu tanggung jawab perawat adalah memonitor kadar glukosa darah pasien saat dalam proses perawatan. Hasil pemantuan kadar glukosa darah hendaknya sesuai dengan target pengobatan dan terhindar dari hipoglikemi. Sasaran glukosa darah pasien diabetes melitus yang dirawat adalah 140-180 mg/dl pada pasien dengan penyakit kritis, dan pada pasien dengan penyakit non-kritis yaitu $<140 \mathrm{mg} / \mathrm{dl}$ untuk glukosa darah puasa, dan $<180 \mathrm{mg} / \mathrm{dl}$ untuk glukosa darah acak (Kubacka, 2014). Selama proses perawatan, pemantauan glukosa darah pada pasien Tn. $\mathrm{R}$ dilakukan berdasarkan kurva gula darah harian yaitu sebelum makan pagi, sebelum makan siang, dan sebelum makan malam.

Intervensi keperawatan kolaborasi dilakukan dengan dokter dalam pemberian insulin untuk manajemen hiperglikemia. Pemberian terapi insulin berupa insulin basal-bolus yang terdiri dari insulin basal (insulin Glargine contohnya Lantus, dan insulin Detemir contohnya Levemir) untuk mencakup kebutuhan insulin basal (sebagian besar karena produksi glukosa hepar) dan insulin prandial atau bolus (insulin Lispro contohnya Humalog, insulin Glulisine contohnya Apidra, dan insulin Aspart contohnya Novorapid) untuk mencakup kebutuhan terhadap berbagai bentuk intake kalori (peningkatan glukosa darah prandial) (Kubacka, 2014; Barnard, Batch, \& Lien, 2010). Terapi insulin yang diberikan pada pasien $\mathrm{Tn}$. $\mathrm{R}$ adalah insulin basal bolus terdiri dari insulin kerja panjang Lantus dan insulin prandial menggunakan insulin kerja cepat yaitu Novorapid. Pemberian Lantus dilakukan dengan satu kali penyuntikan pada malam hari sebelum tidur. Sedangkan Novorapid diberikan setiap kali waktu makan yaitu makan pagi, makan siang, dan makan malam (15 menit sebelum makan) dengan catatan makanan harus telah tersedia.

Kadar glukosa darah berhubungan erat dengan asupan kalori pasien setiap hari. Oleh karena itu residen melakukan kolaborasi dengan ahli gizi untuk menghitung jumlah kebutuhan kalori pasien Tn. R. Residen juga berkolaborasi dengan ahli gizi untuk melakukan edukasi mengenai perencaan 
makan dan asupan makan pasien $\mathrm{Tn}$. $\mathrm{R}$ selama dalam proses perawatan di rumah sakit. Sebagai bentuk pemantauan asupan nutrisi pasien, residen melakukan observasi makan pasien setiap kali jadwal makan untuk mengidentifikasi jumlah asupan porsi makan yang dihabiskan pasien. Hal ini juga berhubungan dengan pemantauan makan setelah injeksi insulin prandial.

Intervensi keperawatan yang diberikan untuk memenuhi kebutuhan belajar dan persiapan pulang pasien adalah dengan edukasi. Edukasi merupakan sebuah dasar penting dalam pengelolaan diabetes melitus. Materi edukasi yang diberikan berhubungan dengan kemampuan untuk bertahan atau survival skill yaitu materi mengenai diabetes melitus dan penatalaksanaannya, perencanaan makan, latihan jasmani, teknik penyuntikan insulin, pemantauan glukosa darah mandiri, tanda dan gejala serta penanganan hipoglikemia, perawatan kaki, dan kontrol teratur (Ackley \& Ladwig, 2011; Dunning, 2009). Proses edukasi dilakukan secara bertahap dan disesuaikan dengan kondisi pasien. Berdasarkan pendekatan evaluasi Orem, setelah proses perawatan nursing system design pasien Tn. $\mathrm{R}$ yaitu partly compensatory. Glukosa darah pasien cenderung fluktuatif dan pasien masih dalam proses belajar penyuntikan insulin mandiri, serta sebagian pemenuhan kebutuhan untuk kestabilan glukosa darah masih dibantu oleh perawat.

Masalah keperawatan ketiga yang ditemukan adalah kelebihan volume cairan. Definisi dari diagnosa kelebihan volume cairan adalah peningkatan cairan isotonis dengan karakteristik yaitu bunyi nafas tambahan, gangguan elektrolit, edema, perubahan tekanan darah, perubahan pola nafas, peningkatan tekanan vena sentral, asupan melebihi haluaran, efusi pleura,kongesti paru, gelisah, bunyi jantung S3 dan penambahan berat badan dalam waktu singkat (NANDA, 2011).
Kelebihan volume cairan tubuh berhubungan dengan berpindahnya cairan dari intravascular dan terakumulasi pada kompartemen interstisial sehingga terjadi peningkatan volume cairan interstisial (ISF). Berdasarkan prinsip Hukum Starling pada kapiler yang menyatakan bahwa kecepatan dan arah pertukaran cairan di antara kapiler dan ISF ditentukan oleh tekanan hidrostatik dan tekanan osmotic koloid dari kedua cairan. Pada kasus Tn.R terdapat kondisi gagal jantung kongestif grade II dan efusi pleura dengan edema ektremitas bawah dan skrotum.

Pada kondisi gagal jantung kongestif, terjadi kegagalan pompa pada ventrikel kiri yang menyebabkan terjadi penurunan volume isi sekuncup. Hal ini menyebabkan terjadi peningkatan volume ventrikel akhir sistolik. Dengan meningkatnya volume sisa ventrikel, hal ini menyebabkan terjadi peningkatan tekanan pada jantung kiri. Kenaikan tekanan ini akan diteruskan ke belakang ke vena pulmonalis sehingga terjadi peningkatan tekanan kapiler dan vena paru. Apabila tekanan hidrostatik anyaman kapiler paru melebihi tekanan onkotik pembuluh darah, maka terjadi transudasi cairan ke dalam interstisial paru. Jika peningkatan tekanan terjadi terus menerus maka akan terjadi edema paru akibat perembesan cairan ke dalam alveoli. Peningkatan cairan pada interstisial paru mengakibatkan peningkatan tekanan interstisial yang akan mengakibatkan cairan berpindah dari interstisial melewati pleura viseralis dan masuk ke dalam rongga pleura. Ketika terjadi suatu edema paru, sekitar 25\% cairan edema akan berpindah ke rongga pleura. Cairan pada rongga pleura sebagian besar akan keluar melalui pembuluh limfe di pleura parietalis dibandingkan cairan yang secara pasif berdifusi melalui pleura viseralis. Jika terjadi peningkatan tekanan vena sistemik seperti pada gagal jantung kongestif, maka pengeleuran cairan dari limfe akan berkurang. Faktor-faktor tersebut mengakibatkan cairan terakumulasi pada rongga pleura (Price \& Wilson, 2005). 
Pada gagal jantung kongestif terjadi kegagalan pompa jantung, dan ketika jantung mulai gagal memompa darah, maka darah akan terbendung pada sistem vena dan bersamaan dengan berkurangnya volume darah pada arteri. Penurunan pengisian arteri ini akan direspon oleh reseptor volume pada pembuluh darah arteri yang memicu aktivitas saraf simpatis yang mengakibatkan vasokonstriksi sebagai usaha untuk mempertahankan curah jantung. Akibat vasokonstriksi maka suplai darah akan diutamakan ke pembuluh darah otak, jantung dan paru, sementara ginjal dan organ lain mengalami penurunan aliran darah. Akibatnya volume darah arteri efektif berkurang dan ginjal akan menahan natrium dan air (Effendi \& Pasaribu, 2014). Mekanisme ini terjadi bersamaan dengan perubahan efek Hukum Starling yang mengatur distribusi cairan antara kapiler dan ruangan interstisial yaitu peningkatan tekanan hidrostatik kapiler vena dan penurunan tekanan osmotic koloid (Price \& Wilson, 2005). Dengan demikian terjadi peningkatan terjadi perpindahan cairan intravascular ke interstisial. Akumuluasi cairan interstisial yang berlebihan mengakibatkan terbentuknya edema. Penyebaran edema generalisata diatur gaya gravitasi yang mempengaruhi tekanan hidrostatik kapiler. Dengan demikian edema biasanya terjadi pada tempat dengan tekanan hidrostatik yang tinggi seperti pada daerah yang rendah yaitu daerah tungkai atau pada tempat dengan tekanan interstisial paling rendah seperti daerah scrotal (Price \& Wilson, 2005). Faktor lain yang menambah penyebab terjadinya edema pada pasien adalah hipoalbumin. Albumin merupakan kontributor utama terhadap tekanan onkotik serum yang membantu pergerakan cairan dari ruangan interstisial ke dalam intravascular. Pada kondisi penurunan kadar albumin serum dapat terjadi edema perifer (Ackley \& Ladwig, 2011).

Intervensi keperawatan yang dilakukan pada masalah kelebihan volume cairan adalah manajemen cairan. Pemantauan intake cairan dan output serta balance cairan penting dilakukan pada pasien dengan kelebihan volume cairan. Observasi edema dilakukan untuk mengkaji lokasi dan penyebaran edema. Pada pasien dengan CHF, peningkatan tekanan hidrostatik mengakibatkan terjadinya edema dependen yang sering terjadi pada kaki. Intervensi kolaborasi dengan medis untuk pemberian terapi diuretic dilakukan untuk evakuasi kelebihan volume cairan. Pada pasien dengan efusi pleura dan edema paru, pemantauan fungsi pernafasan seperti suara nafas, bunyi nafas tambahan, sesak penting untuk dilakukan. Berdasarkan pendekatan evaluasi Orem, setelah proses perawatan nursing system design pasien $\mathrm{Tn}$. $\mathrm{R}$ mengalami perubahan menjadi supportive-educative. Pasien tidak mengalami sesak, ronchi tidak ada, edema skrotalis dan edema tungkai tidak ada, aktivitas ringan sampai sedang disekitar kamar dengan menggunakan kursi roda. Kepatuhan minum obat dilakukan dengan baik dengan arahan dari perawat dan dokter

Masalah selanjutnya yang diangkat pada kasus Tn. $\mathrm{R}$ adalah kerusakan integritas jaringan, yaitu suatu kondisi terjadi keruasakan pada jaringan seperti korna, membrane mukosa, integument atau jaringan subkutan atau adanya jaringan yang hancur (NANDA dalam Ackley \& Ladwig, 2011). Masalah kerusakan integritas jaringan pada pasien Tn. R ditegakkan dengan data yang mendukung yaitu terdapat ulkus kaki diabetik pedis sinistra post debridement mekanik, eksudat minimal, slough terdapat pada luka di sela interdigiti III. Dasar luka terdiri dari jaringan sub kutis, fascia, otot dan tendon berwarna kemerahan. Kulit disekitar luka tampak kemerahan, dan kulit kaki cenderung kering dan retak.

Berdasarkan etiologinya, ulkus kaki diabetik dikategorikan menjadi ulkus iskemik, neuropati, dan gabungan neuropati-iskemik. Walaupun kedua komplikasi mikrovaskular tersebut menjadi faktor utama, pencetusnya bisa stress fisik atau mekanik. Penurunan sirkulasi darah perifer akan menyebabkan berkurangnya perfusi ke tingkat sel sehingga 
mengakibatkan iskemik jaringan sementara neuropati dapat mengakibatkan peningkatan tekanan pada kaki dengan aliran darah yang cukup akan tetapi telah kehilangan sensasi proteksi. Selanjutnya ulkus neuroiskemik merupakan kombinasi efek dari neuropati dan iskemik dengan gangguan perfusi perifer. Selain itu, pada pasien diabetes melitus telah mengalami penurunan imunitas tubuh sehingga rentan terhadap infeksi (International Best Practice Guidelines, 2013; Djokomoeljanto \& Nugroho, 2007). Selain faktor-faktor tersebut, terdapat beberapa faktor yang berkontribusi terhadap kejadian ulkus kaki diabetik yaitu riwayat ulkus atau amputasi sebelumnya, tekanan pad akaki, edema perifer, kallus pada plantar pedis, iskemik, nefropati, retinopati, kontrok glikemik yang buruk, usia tua, dan lama mengalami diabetes melitus.

Pengelolaan ulkus kaki diabetik secara holistik membutuhkan kerja sama multidisiplin yang baik dalam penanganan kasus agar diperoleh hasil pengelolaan yang maksimal. Beberapa aspek yang harus dikelola secara bersama dan menyeluruh adalah kontrol metabolik, kontrol luka, kontrol vaskular, kontrol infeksimikroba, kontrol mekanik-tekanan, dan kontrol edukasi (Waspadji, 2014). Intervensi keperawatan yang residen lakukan pada Tn. $\mathrm{R}$ terintegrasi dalam pengelolaan aspek-aspek tersebut yaitu perawatan luka, kontrol infeksi, off-loading, dan edukasi perawatan kaki diabetik.

Perawatan luka dilakukan untuk mendukung perkembangan proses penyembuhan luka. Konsep dasar dalam proses perawatan luka adalah mempersiapkan dasar luka (wound bed preparation atau WBP) untuk proses penyembuhan. Pada kasus ulkus kaki diabetik, pendekatan konsep WBP dimakusdkan untuk memperbaiki setiap defisiensi yang terdapat pada dasar luka yang dibutuhkan untuk mendukung proses penyembuhan luka dimana proses ini dilakukan dengan segera dan terintegrasi. Aspek-aspek yang dilakukan dalam WBP adalah debridement, kontrol infeksi dan mikroba, kontrol edema dan eksudat, dan intervensi pembedahan terhadap defek yang mendasari (Falanga \& Iwamoto, 2012).

Proses inflamasi yang berlangsung lama dan luas merupakan tanda adanya infeksi. Untuk mengidentifikasi adanya infeksi pada luka sangat dibutuhkan pengkajian yang menyeluruh terhadap tanda dan gejala infeksi serta pemeriksaan kultur mikroba (International Best Practice Guidelines, 2013; Werdin et al., 2009). Tanda dan gejala infeksi yang ditemukan pada pasien $\mathrm{Tn}$. $\mathrm{R}$ adalah pemanjangan fase inflamasi, eritema di sekitar luka, adanya eksudat dan slough, hasil pemeriksaan rontgen pedis menunjukkan adanya lesi litik falang proksimal dan distal digiti I yang dapat disesuaikan dengan gambaran osteomielitis, dan hasil pemeriksaan leukosit $10.100 / \mu \mathrm{L}$. Untuk menentukan jenis mikroba yang menjadi agen infeksi pada luka, perlu dilakukan kultur mikroba. Sampel kultur yang direkomendasikan adalah menggunakan jaringan lunak luka dengan menggunakan teknik biopsi atau kuretase, atau aspirasi sekret purulen, atau dengan teknik deep swabbing. (International Best Practice Guidelines, 2013; Lipsky et al., 2012). Pemeriksaan kultur pada pasien $\mathrm{Tn}$. R menggunakan sampel jaringan lunak luka dan sampel dari teknik deep swabbing. Hasil pemeriksaan kultur jaringan luka menunjukkan terdapat bakteri Enterococcus Sp., Acitenobacter Sp.

Tujuan dilakukan kultur adalah untuk mengetahui jenis mikroba patogen penyebab infeksi dan menentukan pemberian antibiotik definitif yang tepat. Pemberian terapi antibiotik dilakukan sampai terjadi perbaikan kondisi infeksi, tidak sampai luka sembuh. Intervensi selain pemberian antibiotic untuk kontrol infeksi adalah perawatan luka secara berkala sesuai kondisi luka dan debridement.

Perawatan luka yang dilakukan pada pasien Tn. R dilakukan secara berkala setiap sesuai kondisi luka pasien. Setelah dilakukan 
debridement, dilanjutkan dengan perawatan luka dengan mempertimbangkan kondisi luka dan mempersiapkan pemilihan dressing yang tepat. Pemilihan dressing yang tepat harus mendukung konsep moist wound care dan mampu mengontrol pengeluaran eksudat. Dressing yang digunakan sebaiknya dapat menciptakan lingkungan luka yang fisiologis, yaitu moist, dapat mengontrol suhu luka, menjaga kecukupan perfusi jaringan dan kontrol bakteri. Berdasarkan kondisi luka Tn. $\mathrm{R}$ maka dressing primer yang digunakan adalah Cutimed Sorbact Gel karena luka sebagian masih ditutupi slough dengan eksudat minimal dan sebagai dressing sekunder menggunakan kassa. Cutimed Sorbact gel merupakan jenis dressing primer yang terdiri dari dressing Cutimed Sorbact yang dilapisi dengan hydrogel dan merupakan dressing yang dilapisi oleh dialkylcarbamoylchloride sehingga membuat dressing bersifat hidrofobik. Sifat ini mendukung terbentuknya interaksi hidrofobik yang menarik bakteri sehingga berikatan dengan serat dressing dimana ikatan ini bersifat ireversibel. Kandungan hydrogelnya mendukung terciptanya lingkungan moist yang juga memfasilitasi pergerakan bakteri menuju dressing yang akan membentuk ikatan ireversibel antara serat dressing dan bakteri (Pirie, Duguid, \& Timmons, 2009).

Untuk mendukung proses penyembuhan luka, maka perlu menghindari penekanan yang berlebihan pada luka. Hal ini penting dilakukan karena penekanan yang berlebihan pada luka akan menghambat pertumbuhan jaringan baru dan merusak jaringan yang telah terbentuk. Selanjutnya dengan prinsip offloading ini dapat mendistribusikan tekanan luka secara merata pada bidang datar (International Best Practice Guidelines, 2013). Sementara itu proses memandirikan pasien terus berjalan dimana pasien mulai memenuhi kebutuhan self care eliminasi dan aktivitas secara mandiri. Intervensi yang dilakukan adalah membantu memenuhi kebutuhan self care pasien dan tetap memperhatikan prinsip off-loading pada luka yaitu dengan menggunakan kassa tebal sebagai dressing sekunder dan ditutup perban elastik untuk mengurangi tekanan berlebihan pada luka. Untuk membantu pasien memenuhi kebutuhannya dan menghindari tekanan berlebihan pada daerah plantar, maka pasien menggunakan kursi roda. Pasien mampu menggunakan kursi roda untuk memenuhi kebutuhan eliminasi dan aktivitas dan luka terhindar dari penekanan yang berlebihan.

Intervensi selanjutnya yang dilakukan untuk mendukung proses penyembuhan luka berhubungan dengan kontrol metabolik. Salah satu indikator kontrol metabolik adalah kadar albumin dan glukosa darah. Albumin adalah protein utama yang disintesis oleh hepar dimana albumin mempertahankan tekanan onkotik plasma dan transport nutrisi di dalam aliran darah. Penurunan kadar albumin dapat menyebabkan edema, luka terbuka dan meningkatkan resiko infeksi. Penurunan kadar albumin juga berhubungan dengan kondisi klinis yang buruk, meningkatkan lama rawat, dan meningkatkan resiko komplikasi dan kematian. Pada pasien diabetes melitus dengan ulkus kaki diabetik, terjadi peningkatan sintesis fibrinogen dan $\mathrm{C}$-reactive protein (CRP) akibat proses inflamasi. Hal ini menyebabkan penurunan kadar albumin serum akibat peningkatan sintesis protein fase akut dan penurunan sintesis homeostasis protein di hepar (Rehm, 2003). Selain itu, beberapa kondisi pada pasien diabetes melitus yang menyebabkan kadar albumin yang rendah yaitu proses katabolisme pada diabetes melitus akibat defisiensi insulin dan menyebabkan fenomena neoglukoneogenesis berlansung terus menerus yang mengubah asam amino dan lemak menjadi glukosa; pada pasien diabetes melitus dengan komplikasi nefropati yang mengalami mikro dan makroalbuminuria dan nefropati diabetik lanjut menyebabkan proteinuria, yang menjadi sumber kehilangan protein (Hendromartono, 2014); kehilangan protein akibat produksi eksudat pada luka yang luas dan dalam; akibat asupan diet rendah 
protein pada pasien dengan kerusakan ginjal akibat komplikasi diabetik (Tatti \& Barber, 2011).

Perawat memiliki peran yang penting dalam pencegahan terjadinya ulkus kaki diabetik dan amputasi ekstremitas melalui skrining kaki diabetik dan edukasi perawatan kaki diabetik. Menjadi sebuah kebutuhan penting bagi pasien diabetes melitus dengan resiko tinggi ulkus kaki diabetik dan keluarganya untuk mendapatkan edukasi tentang dasar perawatan kaki mandiri. Hal ini sangat penting karena edukasi terbukti efektif dalam pencegahan ulkus kaki diabetik (Aalaa, Malazy, Sanjari, Pelmani, \& Mohajeri-Tehrani, 2012). Pasien Tn. R memiliki riwayat ulkus kaki diabetik sebelumnya, dan berdasarkan etiologi terjadinya luka disebabkan oleh perilaku perawatan kaki pasien yang buruk. Oleh karena itu edukasi tentang perawatan kaki mandiri harus dilakukan untuk mencegah kejadian ulkus berulang. Residen memberikan edukasi kepada pasien dan keluarga mengenai perawatan kaki dirumah, mulai dari pemeriksaan kaki harian, perawatan kaki melalui cuci kaki dengan sabun, menjaga kelembaban kulit, menggunakan alas kaki yang tepat, dan menjelaskan kepada pasien hal-hal yang perlu dihindari atau tidak boleh dilakukan. sementara itu, untuk menjaga kebersihan kaki, residen menganjurkan pasien dan keluarga untuk menjaga kebersihan kaki dan menggunakan pelembab untuk menjaga kelembaban kulit kaki pasien. Residen menganjurkan untuk menggunakan minyak kelapa murni sebagai moisturizer alami kulit. Selain sebagai moisturizer, kandungan monolaurin pada minyak kelapa murni memiliki efek antibakteri dan jamur yang dapat melindungi kulit dari infeksi (VeralloRowell, Dillague, \& Syah-Tjundawan, 2008). Berdasarkan pendekatan evaluasi Orem, setelah proses perawatan nursing system design pasien $\mathrm{Tn} . \mathrm{R}$ adalah partly compensatory. Walaupun proses penyembuhan luka telah berlangsung, pasien membutuhkan perawatan dari tim kesehatan untuk mengelola ulkus kaki diabetik.

Masalah keperawatan selanjutnya yang diangkat adalah resiko ketidakseimbangan elektrolit yang merupakan kondisi dimana seseorang beresiko mengalami perubahan kadar elektrolit serum yang dapat mengganggu kesehatan. Faktor resiko yang berhubungan dengan kondisi ini yaitu ketidakseimbangan cairan (dehidrasi, kelebihan cairan) dan disfungsi ginjal (NANDA, 2011). Dari hasil pengkajian ketidakseimbangan elektrolit yang ditemukan adalah hiponatremia dan hipokloremia.

Natrium merupakan kation yang paling banyak ditemukan pada ECF dan merupakan faktor utama yang mempengaruhi osmolalitas ECF. Jika kadar natrium serum kurang dari 135 $\mathrm{mEq} / \mathrm{L}$, maka pasien mengalami hiponatremia. Pada pasien dengan krisis hiperglikemia seperti KAD, terjadi peningkatan kadar glukosa darah yang melebihi ambang batas ginjal sehingga mengakibatkan diuresis osmotic dan hal ini akan menyebabkan dehidrasi dan kehilangan mineral dan elektrolit seperti natrium, kalium, klorida, kalsium, magnesium, fosfat. Nilai ambang ginjal terhadap kadar glukosa darah $( \pm 200 \mathrm{mg} / \mathrm{dl})$ dan keton akan terlampaui, sehingga terjadi ekskresi glukosa melalui ginjal yang mencapai $200 \mathrm{~g} / \mathrm{hari}$ dan keton urine yang mencapai $\pm 20-30 \mathrm{~g} / \mathrm{hari}$, dengan total osmolaritas urine $\pm 2000 \mathrm{mOsm}$. Efek osmotic akibat kondisi glukosuria dapat berdampak pada gangguan reabsorbsi $\mathrm{Na}$ dan $\mathrm{Cl}$ dan air di tubulus proksimal lengkung Henle (Faizi \& Netty, 2005).

Bentuk lain hiponatremia adalah hiponatremia dilusional dimana pada kondisi ini terjadi kelebihan air dalam tubuh yang dapat ditemukan pada kondisi seperti gagal jantung (Price \& Wilson, 2005). Pada kondisi gagal jantung, terjadi penurunan cardiac output yang dapat melemahkan sensitivitas baroreseptor. Penurunan respon baroreseptor (yang terdapat 
pada atrium kiri, sinus karotis, arkus aorta, arteriol aferen ginjal) disebabkan oleh penurunan tekanan arterial sistemik, stroke volume, dan perfusi renal atau resistensi vaskular perifer. Penurunan volume darah sirkulasi efektif seperti kondisi gagal jantung akan mengganggu sensitivitas baroreseptor, dan mengarah pada meningkatkan aktivitas sistem saraf simpatis (nervus vagal) yang mengaktivasi sistem renin-aldosteronangiotensi dan hormon antidiuretik vasopressin arginine (AVP). Ikatan antara AVP dengan $\mathrm{V}_{2}$ reseptor di duktus kolektivus ginjal akan meningkatkan retensi air, dimana proses ini akan mengarah pada hiponatremia dilusional (Ishikawa, 2015; Goldsmith, 2010).

Intervensi yang dilakukan untuk mengatasi resiko ketidakseimbangan elektrolit adalah dengan manajemen elektrolit. Monitor tandatanda vital sangat penting untuk memantau hemodinamik pasien. Pengkajian terhadap adanya gangguan neuromuscular dilakukan untuk mengidentifikasi dampak dari ketidakseimbangan elektrolit. Monitor hasil pemeriksaan elektrolit dilakukan untuk mengevaluasi pengobatan. Pemberian terapi cairan dan elektrolit diberikan berupa cairan $\mathrm{NaCl} 0,9 \%$. Pada hiponatremia dengan kadar natrium serum antara 115 - $130 \mathrm{mmol} / \mathrm{L}$, koreksi natrium dilakukan dengan pemberian cairan $\mathrm{NaCl} 0,9 \%$. Pemberian cairan dipantau dengan balance cairan, karena pasien mengalami CHF. Berdasarkan pendekatan evaluasi Orem, setelah proses perawatan nursing system design pasien Tn. R mengalami perubahan menjadi supportive-educative. Kadar elektrolit dalam batas normal, dan pasien tidak mengalami gangguan neurologis.

\section{Penerapan Evidence Based Nursing Practice}

Kaki diabetik merupakan sebuah komplikasi yang sering terjadi pada kasus diabetes melitus akibat kontrol glikemik yang buruk. Neuropati, penyakit arteri perifer, deformitas bentuk kaki, merupakan bentuk-bentuk komplikasi kronis kaki diabetik yang terjadi pada pasien diabetes melitus. Kombinasi dari kondisi tersebut dan ditambah dengan cedera fisik dapat menimbulkan cedera pada kaki dan rentan mengalami infeksi yang dapat mengakibatkan terjadinya ullkus kaki diabetik. Selain kendali diabetes untuk mengontrol glikemik, profil lipid, tekandan darah, tindakan yang dapat dilakukan oleh pasien diabetes melitus untuk mencegah terjadinya ulkus kaki diabetik adalah dengan melakukan perawatan kaki mandiri.

Suitor (2007) menyebutkan bahwa perilaku perawatan kaki merupakan suatu perilaku yang dilakukan oleh pasien diabetes melitus untuk merawat kaki. Bagi pasien diabetes melitus yang telah mengalami neuropati seperti kulit kering dan retak-retak, kehilangan sensasi di kaki, baal, kelainan bentuk kaki, dan gangguan sirkulasi kaki, sangat penting untuk melakukan perawatan kaki mandiri. Perawatan kaki mandiri yang dilakukan setiap hari akan mengurangi resiko terjadinya amputasi minor dan mayor (Frisch, 2012).

Intervensi yang dapat diberikan untuk meningkatkan pengetahuan dan perilaku perawatan kaki adalah melalui edukasi. Edukasi dapat meningkatkan pengetahuan dan berdampak pada perilaku perawatan kaki diabetes. Informasi yang diberikan dalam proses edukasi berisi topik yang terstandarisasi dan spesifik diberikan kepada pasien sesuai dengan faktor resiko, pengetahuan, dan perilaku perawatan kaki yang telah dilakukan. Topik standar yang diberikan kepada pasien diabetes melitus dalam edukasi perawatan kaki diabetik yaitu faktor resiko komplikasi kaki diabetik, pemeriksaan kaki, mencuci dan mengeringkan kaki, perawatan kuku, penggunaan alas kaki, menjaga kelembaban kaki, dan kontrol jika terjadi masalah kaki (Corbett, 2003).

Berdasarkan rerata skor pengetahuan dan perilaku perawatan kaki diabetik sebelum dan sesudah intevensi edukasi, ditemukan bahwa 
terjadi peningkatan rerata skor pengetahuan dan perilaku perawatan kaki setelah dilakukan intervensi edukasi. Hal ini menunjukkan bahwa edukasi yang diberikan dapat meningkatkan perilaku perawatan kaki diabetik pada pasien diabetes. Metode edukasi yang diterapkan yaitu dengan instruksi verbal melalui penjelasan dan ceramah, instruksi tertulis menggunakan booklet, dan demonstrasi dapat meningkatkan nilai perilaku perawatan kaki. Hasil ini sesuai dengan hasil penelitian yang dilakukan oleh Corbett (2003) yang menunjukkan bahwa intervensi edukasi dapat meningkatkan pengetahuan dan perawatan kaki diabetik.

Edukasi pasien merupakan salah satu peran yang penting yang dilakukan oleh perawat. Perawat harus membuat suatu model edukasi yang tepat bagi pasien. Perawat berperan dalam menyediakan informasi yang dibutuhkan pasien untuk melakukan perawatan mandiri untuk memastikan kelanjutan perawatan dari rumah sakit ke rumah pasien. Edukasi yang diberikan kepada pasien harus mempertimbangkan pengalaman dan tingkat pendidikan pasien, keinginan pasien untuk terlibat dalam proses edukasi, dan kondisi psikosial, spiritual, dan budaya (Potter et al., 2013).

Perawat memiliki peran yang penting dalam pencegahan terjadinya ulkus kaki diabetik dan amputasi ekstremitas melalui skrining kaki diabetik dan edukasi perawatan kaki diabetik. Menjadi sebuah kebutuhan penting bagi pasien diabetes melitus dengan resiko tinggi ulkus kaki diabetik dan keluarganya untuk mendapatkan edukasi tentang dasar perawatan kaki mandiri. Hal ini sangat penting karena edukasi terbukti efektif dalam pencegahan ulkus kaki diabetik. Perawat dapat memberikan edukasi kepada pasien dan keluarga mengenai pemeriksaan kaki dan perawatan kaki mandiri setiap hari. Selanjutnya, perawat dapat mendorong pasien untuk melakukan tindakan yang akan melindungi kaki mereka dari cedera atau mencegah ulkus berulang seperti pemeriksaan sepatu sebelum dan sesudah dipakai, menjaga kebersihan dan kelembaban kulit dan kebersihan kuku, serta pemilihan alas kaki yang tepat (Aalaa et al., 2012).

Edukasi merupakan suatu proses yang terdapat proses mengajar (teaching) dan belajar (learning). Perawat memiliki tanggungjawab etik untuk mengajar pasien mereka dengan memberikan informasi yang pasien dan keluarga butuhkan. Selain itu, perawat juga harus menentukan kebutuhan belajar pasien dan kapan pasien siap untuk belajar. Sementara itu, proses belajar (learning) terdiri dari 3 domain yaitu kognitif, afektif, dan psikomotor. Beberapa topik kesehatan membutuhkan kombinasi tiga domain proses belajar, diantaranya masalah diabetes melitus (Potter et al., 2013). Untuk proses belajar, residen menggunakan gabungan metode instruksi belajar untuk memfasilitasi proses belajar yaitu diskusi individu dan demonstrasi, kemudian menggunakan media belajar yaitu booklet dan alat perawatan kaki. Dalam domain proses belajar, residen berusaha memenuhi kebutuhan belajar dari 3 domain yaitu kognitif, afektif, dan psikomotor. Domain kognitif dengan memberikan informasi mengenai bagaimana dampak diabetes melitus terhadap tubuh yang lebih spesifik terhadap komplikasi kaki diabetes. Selanjutnya untuk domain afektif, residen mengidentifikasi perilaku perawatan kaki yang selama ini dilakukan pasien di rumah. Sedangkan untuk domain psikomotor, yaitu dengan mengajarkan bagaimana perawatan kaki mandiri di rumah dengan demonstrasi dan menggunakan perlengkapan yang telah disediakan oleh residen.

Selama proses penerapan EBN edukasi perawatan kaki mandiri, terhadap beberapa faktor yang mempengaruhi implementasi dan evaluasi. Dalam proses implementasi edukasi, salah satu faktor yang mempengaruhi adalah lingkungan edukasi. Potter et al. (2013) menjelaskan bahwa faktor lingkungan fisik 
mempengaruhi proses edukasi yang dapat berdampak bagi pasien yaitu memudahkan proses edukasi atau sebaliknya membuat proses edukasi menjadi lebih sulit. Beberapa hal yang harus diperhatikan antara lain privasi pasien, suhu ruangan, pencahayaan, kebisingan, ventilasi udara, dan pengaturan tempat. Evaluasi proses edukasi yang residen lakukan adalah lingkungan belajar yang kurang kondusif, yaitu ruangan yang terdapat banyak orang karena harus berbagi tempat dengan residen yang lain, ruangan edukasi yang digunakan bersama dengan profesi lain yang juga sedang melakukan diskusi sehingga menimbulkan suara yang dapat mengganggu proses edukasi.

Rekomendasi dari hasil penerapan EBN ini adalah edukasi perawatan kaki bagi pasien diabetes melitus akan meningkatkan pengetahuan dan perilaku perawatan kaki. Di tempat penerapan EBN ini, proses edukasi telah dilakukan akan tetapi bersifat oportunistik dan tidak terstruktur. Selain itu, lingkungan yang kurang mendukung akan mempengaruhi proses edukasi. Oleh karena itu perlu dibentuk suatu model edukasi bagi pasien diabetes dengan menyediakan perawat edukator khusus yang menyediakan edukasi bagi pasien diabetes dan ruangan khusus edukasi dengan berbagai media edukasi. Hal ini sejalan dengan rencana pengembangan poliklinik endokrin metabolik rumah sakit yaitu untuk mengembangkan poliklinik edukasi dengan tenaga edukator khusus yang bertanggung jawab dalam kegiatan edukasi pasien.

\section{Inovasi Keperawatan}

Pengelolaan diabetes melitus yang diintegrasikan dalam aktivitas kehidupan sehari-hari membutuhkan pengetahuan dan kemampuan yang bersifat keterampilan khusus jika dibandingkan dengan pengelolaan penyakit kronis yang lain (Fonseca, Pendergrass, \& McGuffie, 2010). Pengetahuan yang harus dimiliki pasien diabetes melitus yaitu pemeriksaan glukosa darah secara mandiri dan memahami apa tindak lanjut yang harus dilakukan saat itu sesuai dengan hasil pemantauan kadar glukosa darah, memahami gejala-gejala komplikasi baik akut maupun kronis, pengobatan $\mathrm{OHO}$ diminum dengan jadwal pengaturannya, penyuntikan insulin basal maupun prandial, pengaturan jadwal dan jenis makanan yang benar, berolahraga, dan lain sebagainya.

Sebanyak 16 orang ikut berpartisipasi dalam program inovasi. Rata-rata umur responden adalah 54,31 tahun dengan usia termuda 40 tahun dan tertua 68 tahun. Hasil estimasi interval menunjukkan bahwa rata-rata umur responden diabetes melitus yang berpartisipasi dalam kegiatan inovasi keperawatan berada pada rentang usia 50,31-58,31 tahun. Hasil ini sesuai dengan hasil disurvei yang dilakukan oleh International Diabetes Federation tahun 2014 yakni, rata-rata usia orang dengan diabetes di dunia adalah 40-59 tahun (IDF, 2014 ).

Hasil quick quiz self health assessment tentang pengetahuan DM menunjukkan bahwa 8 orang memiliki pengetahuan yang baik dan 2 responden memiliki pengetahuan yang kurang. Pengetahuan pasien tentang DM salah satunya didapatkan dari kegiatan edukasi yang diterima. Edukasi merupakan proses perpindahan informasi dari suatu sumber untuk menambah pengetahuan, keterampilan, dan sikap yang diharapkan menampilkan satu perubahan perilaku (Notoatmodjo, 2010). Edukasi DM merupakan pendidikan dan pelatihan mengenai pengetahuan dan keterampilan bagi pasien DM guna menunjang perubahan perilaku, meningkatkan pemahaman pasien tentang penyakitnya, sehingga tercapai kesehatan yang optimal, penyesuaian keadaan psikologis dan peningkatan kualitas hidup (Dunning, 2009).

Hasil quick quiz self health assessment tentang resiko hipoglikemia menunjukkan bahwa terdapat 2 responden beresiko mengalami 
hipoglikemi dan 8 responden tidak beresiko hipoglikemi. Menurut Manaf (2014), hipoglikemia merupakan sebuah terminologi klinis yang digunakan untuk keadaan yang disebabkan oleh menurunnya kadar glukosa darah sampai pada tingkat tertentu sehingga memberikan keluhan. Beberapa etiologi terjadinya hipoglikemia diantaranya penggunaan obat-obatan seperti insulin, sulfonylurea yang berlebihan yang umumnya terjadi pada kasus diabetes melitus. Beberapa hal yang menjadi faktor resiko hipoglikemi pada pasien diabetes melitus yaitu asupan karbohidrat yang kurang yang tidak sesuai dengan dosis insulin yang diinjeksikan, tempat penyuntikan insulin yang tidak tepat, kesalahan dosis insulin, dan setelah berolahraga (Boedisantoso, 2013). Tindakan pencegahan terhadap hipoglikemia yang dapat dilakukan adalah penyuntikan insulin yang tepat, mengantisipasi hipoglikemia setelah berolahraga dengan sarapan sebelum berolahgara. Edukasi tentang tanda dan gejala hipoglikemi, dan penatalaksanaan hipoglikemi merupakan bagian dari survival skill pasien diabetes melitus (Dunning, 2009).

Hasil quick quiz self health assessment menunjukkan bahwa sebanyak 5 responden beresiko terkena komplikasi kaki diabetik, dan 5 responden tidak beresiko. Perjalanan komplikasi diabetes melitus telah berlansung seiring perkembangan penyakit. Salah satu komplikasi mikrovaskular yang terjadi pada pasien diabetes melitus yaitu neuropati baik otonom, sensorik, dan motorik dan gangguan sirkulasi perifer yang terjadi pada kaki atau disebut kaki diabetes. Kaki diabetes adalah kelainan tungkai bawah akibat diabetes melitus yang tidak terkendali (hiperglikemik kronis). Kelainan kaki diabetes melitus dapat disebabkan adanya gangguan pembuluh darah, gangguan saraf, dan adanya infeksi (Tambunan \& Gultom, 2013). Tindakan pencegahan yang dapat dilakukan oleh pasien diabetes melitus yaitu dengan mengelola diabetes melitus dengan optimal yang ditandai dengan kendali glikemik yang baik dan perawatan kaki mandiri di rumah.

Gambaran tingkat kepuasan berdasarkan hasil pengisian kuesioner menunjukkan bahwa sebanyak 14 pasien DMT $2(87,5 \%)$ dikatakan puas, sedangkan 2 pasien $(12,5 \%)$ kurang puas terhadap program promosi kesehatan pada pasien diabetes melitus dengan self-health assessment dan booklet edukasi pengelolaan diabetes mellitus. Hal ini menunjukkan bahwa tingkat kepuasan terhadap adanya program signifikan. Hasil ini menggambarkan bahwa perlu adanya evaluasi dari poli endokrin untuk mempertimbangkan keberlanjutan dari program tersebut.

Salah satu peran dan fungsi perawat dalam melakukan intervensi keperawatan pada individu dan masyarakat adalah sebagai edukator. Dalam konteks perawatan bagi individu DM memberikan edukasi adalah hal yang sangat penting dan menjadi salah satu pilar berhasilnya mencapai kendali diabetes yang baik. Kegiatan inovasi kelompok yang telah dilakukan merupakan salah satu bentuk upaya perawat untuk meningkatkan pengetahuan dan kapasitas individu DM agar memiliki kemampuan self-care yang baik. Dalam proses implementasi edukasi, salah satu faktor yang mempengaruhi adalah lingkungan edukasi. Potter et al. (2013) menjelaskan bahwa faktor lingkungan fisik mempengaruhi proses edukasi yang dapat berdampak bagi pasien yaitu memudahkan proses edukasi atau sebaliknya membuat proses edukasi menjadi lebih sulit. Beberapa hal yang harus diperhatikan antara lain privasi pasien, suhu ruangan, pencahayaan, kebisingan, ventilasi udara, dan pengaturan tempat. Evaluasi proses pelaksanaan proyek inovasi yaitu lingkungan yang kurang kondusif, yaitu ruang tunggu yang penuh dengan pasien, bising, dan mengganggu konsentrasi. Pasien yang mengisi quick quiz akan terganggu dengan ketidaknyamanan yang tejadi. Proses edukasi dilakukan secara individu, akan tetapi di ruangan yang bersama 
pasien dan residen yang lain sehingga kurang nyaman bagi pasien dan cukup mengganggu proses edukasi. Oleh karena itu, selanjutnya dibutuhkan ruangan khusus edukasi dan konseling bagi pasien diabetes melitus dengan perawat khusus edukator diabetes melitus yang bertanggung jawab dan berperan dalam proses edukasi pasien.

\section{KESIMPULAN}

Diabetes melitus merupakan suatu penyakit kronis yang sampai saat belum dapat disembuhkan sehingga membutuhkan penatalaksanaan secara komprehensif yang secara aktif melibatkan pasien dalam proses pengelolaannya. Pasien diharapkan dapat melakukan pengelolaan terhadap penyakitnya secara mandiri. Untuk mencapai tujuan tersebut, pasien harus memiliki kemampuan manajemen perawatan mandiri atau self care. Self-care pada pasien diabetes adalah upaya mandiri yang dilakukan oleh pasien diabetes untuk mengelola penyakitnya. Teori Self Care merupakan pendekatan yang memungkinkan dalam membentuk perilaku self care mandiri pasien diabetes melitus.

Penerapan evidence based nursing practice edukasi perawatan kaki mandiri pada pasien diabetik berdampak positif terhadap peningkatan pengetahuan dan perilaku perawatan kaki mandiri pasien diabetes melitus. Dengan perilaku perawatan kaki yang optimal diharapkan dapat mengurangi resiko terjadinya komplikasi ulkus kaki diabetik.

Kegiatan inovasi peningkatan promosi kesehatan melalui pemeriksaan dan pemantauan kesehatan mandiri memberikan kesempatan kepada pasien untuk melakukan pengkajian mandiri terhadap kebutuhan edukasi mereka. Tindak lanjut dari hasil pengkajian tersebut adalah dengan memberikan edukasi sesuai kebutuhan pasien dan booklet yang berisi materi edukasi pengelolaan diabetes melitus. Pasien menunjukkan tingkat kepuasan yang baik terhadap program inovasi ini.

\section{UCAPAN TERIMA KASIH}

Ucapan terima kasih disampaikan kepada Prof. Dr. Ratna Sitorus, M.App.Sc dan Lestari Sukmarini, SKp, MNS selaku supervisor dan pembimbing yang telah memberikan bimbingan, arahan, masukan dan saran selama proses praktik klinik dan penyusunan karya ilmiah ini.

\section{REFRENSI}

Aalaa, M., Malazy, O. T., Sanjari, M., Peimani, M., \& Mohajeri-Tehrani, M. (2012). Nurses' role in diabetic foot prevention and care: A review. $J$ Diabetes Metab Disord, 11(1), 24.

Ackley, B. J. \& Ladwig, G. B. (2011). Nursing diagnosis handbook: An evidence-based guide to planning care $\left(9^{\text {th }} \mathrm{Ed}\right.$.). St. Louis, MO: Mosby Elsevier.

Alsahli, M., \& Gerich, J. E. (2010). Abnormalities of insulin secretion and $\beta$ cell defects in type 2 diabetes. In R. I. G. Holt, C. Cockram, A. Flyvbjerg, B. J. Goldstein (Eds.)., Textbook of diabetes ( $4^{\text {th }} \quad$ Ed.). $\quad$ Retrieved from http://en.bookfi.org.

Balai Penelitian dan Pengembangan Kesehatan Kementerian Kesehatan RI. (2013). Riset kesehatan dasar 2013. Retrieved from http://depkes.go.id/downloads/riskesdas2 013/Hasil\%20Riskesdas\%202013.pdf.

Barnard, K., Batch, B. C., \& Lien, L. F. (2010). Subcutaneous insulin: a guide for dosing regimens in the hospital. In Glycemic Control in the Hospitalized Patient (pp. 7-16). Springer New York.

Boedisantoso, A. R. (2013). Komplikasi akut diabetes melitus. In S. Soegondo, P. Soewondo \& I. Subekti (Eds.), Penatalaksanaan diabetes melitus terpadu ( $2^{\text {nd }}$ Ed.). Jakarta: Badan Penerbit FK UI. 
Casqueiro, J., Casqueiro, J., \& Alves, C. (2012). Infections in patients with diabetes mellitus: A review of pathogenesis. Indian Journal of Endocrinology and Metabolism, 16(Suppl1), S27.

Corbett, C. F. (2003). A randomized pilot study of improving foot care in home health patients with diabetes. The Diabetes Educator, 29(2), 273-282.

Djokomoeljanto, R. K., \& Nugroho, K. H. HS. (2007). Patofisiologi komplikasi vaskular pada diabetes melitus perhatian khusus pada peripheral arterial disease (PAD). In T. Suhartono, T. G. D. Pemayun, K. H. Nugroho HS (Eds.)., Naskah lengkap kursus manajemen holistik kaki diabetik. Semarang: Badan Penerbit Universitas Diponegoro.

Dunning, T. (2009). Care of people with diabetes: A manual of nursing practice $\left(3^{\text {rd }} \quad\right.$ Ed.). $\quad$ Retrieved from http://en.bookfi.org.

Effendi, I., \& Pasaribu, R. (2014). Edema patofisiologi dan penangannya. In S. Setiati, I. Alwi, A. W. Sudoyo, M. Simadibrata, B. Setiyohadi, A. F. Syam (Eds.), Buku ajar ilmu penyakit dalam (6 ${ }^{\text {th }}$ Ed.). Jakarta: Interna Publishing.

Faizi, M., \& Netty, E. P. (2005). Tatalaksana ketoasidosis diabetik pada anak. Retrieved from http://old.pediatrik.com/pkb/2006022057kf6s-pkb.pdf

Falanga, V., \& Iwamoto, S. (2012). Mechanisms of wound repair, wound healing, and wound dressing. Fitzpatrick's dermatology in general medicine ( $8^{\text {th }}$ Ed.). McGraw-Hill, New York.

Fonseca, V. A., Pendergrass, M., \& McDuffie, R. H. (2010). Diabetes in clinical practice. Retrieved from http://en.bookfi.org.

Frank, K. I. (2003). Self-management of foot care for patients 65 years of age or older with diabetes. 3108609 D.N.S., Indiana University School of Nursing, Ann
Arbor. Retrieved from http://search.proquest.com/docview/305 269764? accountid=17242 ProQuest Dissertations \& Theses Full Text; ProQuest Nursing \& Allied Health Source database.

Frisch, D. R. (2012). Take care of your feet for a lifetime: A booklet for people with diabetes. National diabetes education program. Retrieved from http://ndep.nih.gov/media/NDEP4_Take CareOfFeet_4c_508.pdf.

Gabbay, R. A., \& Adelman, A. M. (2010). Future models of diabetes care. In R. I. G. Holt, C. Cockram, A. Flyvbjerg, B. J. Goldstein (Eds.)., Textbook of diabetes $\left(4^{\text {th }} \quad\right.$ Ed. $) . \quad$ Retrieved from http://en.bookfi.org.

Goldsmith, S. R. (2010). Treatment options for hyponatremia in heart failure. Congestive Heart Failure, 16(s1), S15S18.

Hammersley, M. S., \& James, J. (2010). InHospital treatment and surgery in patients with diabetes. In R. I. G. Holt, C. Cockram, A. Flyvbjerg, B. J. Goldstein (Eds.)., Textbook of diabetes $\left(4^{\text {th }} \quad\right.$ Ed. $) . \quad$ Retrieved from http://en.bookfi.org.

Hendromartono. (2014). Nefropati diabetik. In S. Setiati, I. Alwi, A. W. Sudoyo, M. Simadibrata, B. Setiyohadi, A. F. Syam (Eds.), Buku ajar ilmu penyakit dalam ( $6^{\text {th }}$ Ed.). Jakarta: Interna Publishing.

Herdman, T. H. (2009). NANDA international diagnose keperawatan: Definisi dan klasifikasi, 2009-2011. Jakarta: EGC

International Diabetes Federation (2013). IDF Diabetes atlas (6 ${ }^{\text {th }}$ Ed.). Retrieved from http://www.idf.org/sites/default/files/EN _6E_Atlas_Full_0.pdf.

International Best Practice Guidelines: Wound Management in Diabetic Foot Ulcers (2013). Wounds International. Available from: www.woundsinternational.com

Ishikawa, S. E. (2015). Hyponatremia associated with heart failure: Pathological role of vasopressin- 
dependent impaired water excretion. Journal of Clinical Medicine, 4(5), 933947.

Kubacka, B. (2014). A balancing act: Achieving glycemic control in hospitalized patients. Nursing 2014, 44(1), 30-37.

Leu, J. P., \& Zonnszein, J. (2010). Diagnostic criteria and classification of diabetes. In L. Poretsky (Ed.), Principles of diabetes mellitus ( $2^{\text {nd }}$ Ed.). Retrieved from http://en.bookfi.org.

Lipsky, B. A., Berendt, A. R., Cornia, P. B., Pile, J. C., Peters, E. J., Armstrong, D. G., ... \& Senneville, E. (2012). 2012 Infectious diseases society of America clinical practice guideline for the diagnosis and treatment of diabetic foot infections. Clinical Infectious Diseases, 54(12), e132-e173.

Loveman, E., Royle, P., \& Waugh, N. (2009). Specialist nurses in diabetes mellitus. The Cochrane Library.

Manaf, A. (2014). Hipoglikemi: Pendekatan klinis dan penatalaksanaan. In S. Setiati, I. Alwi, A. W. Sudoyo, M. Simadibrata, B. Setiyohadi, A. F. Syam (Eds.), Buku ajar ilmu penyakit dalam (6 $6^{\text {th }}$ Ed.). Jakarta: Interna Publishing

Marshal, M. S., \& Flyvbjerg, A. (2010). Diabetic nephropathy. In R. I. G. Holt, C. Cockram, A. Flyvbjerg, B. J. Goldstein (Eds.)., Textbook of diabetes $\left(4^{\text {th }} \quad\right.$ Ed. $) . \quad$ Retrieved from http://en.bookfi.org.

Pirie, G., Duguid, K., \& Timmons, J. (2009). Cutimed ${ }^{\circledR}$ Sorbact ${ }^{\circledR}$ gel: A new infection management dressing. Wounds $U K, 5(2), 74-8$.

Potter, P. A., Perry, G. A, Stockert, A. P., \& Hall, M. A. (2013). Fundamentals of nursing $\left(8^{\text {th }}\right.$ Ed.). Missouri: Elsevier Mosby.

Price, S. A., \& Wilson, L. M. (2005). Patofisiologi: Konsep klinis prosesproses penyakit. Jakarta: EGC
Rehm, K. B. (2003). Nutritional aspects of healing a diabetic foot wound. Podiatry Management, 22(9), 199-212.

Suitor, M. (2007). Foot care knowledge, practice and self-efficacy of people with type 2 diabetes, with and without lower limb ulceration. (Order No. MR33183, University of Alberta (Canada)). ProQuest Dissertations and Theses, , 82n/a. Retrieved from http://search.proquest.com/docview/304 777139? accountid=17242. (304777139).

Tambunan, M., \& Gultom, Y. (2013). Perawatan kaki diabetes. In S. Soegondo, P. Soewondo \& I. Subekti (Eds.), Penatalaksanaan diabetes melitus terpadu ( $2^{\text {nd }}$ Ed.). Jakarta: Badan Penerbit FK UI.

Tatti, P., \& Barber, A. (2011). Nutritional treatment of diabetic foot ulcers - a key to success. INTECH Open Access Publisher.

http://cdn.intechopen.com/pdfswm/24695.pdf

Trojan, L., \& Yonge, O. (1993). Developing trusting, caring relationships: home care nurses and elderly clients. Journal of Advanced Nursing, 18(12), 1903-1910.

Verallo-Rowell, V. M., Dillague, K. M., \& Syah-Tjundawan, B. S. (2008). Novel antibacterial and emollient effects of coconut and virgin olive oils in adult atopic dermatitis. Dermatitis, 19(6), 308315.

Waspadji, S. (2014). Kaki diabetes. In S. Setiati, I. Alwi, A. W. Sudoyo, M. Simadibrata, B. Setiyohadi, A. F. Syam (Eds.), Buku ajar ilmu penyakit dalam (6 $6^{\text {th }}$ Ed.). Jakarta: Interna Publishing

Werdin, F., Tennenhaus, M., Schaller, H. E., \& Rennekampff, H. O. (2009). Evidence-based management strategies for treatment of chronic wounds. Eplasty, 9.

Wilkinson, J. M. (2006). Buku saku diagnosis keperawatan. Jakarta: EGC. 